\title{
Yoğun bakım ünitesinde bolus ve sürekli infüzyon ile beslenen hastaların kan glukozu regülasyonlarının karşılaştırılması
}

\author{
Emsal KARACA ${ }^{\mathrm{a}}$, Elif KARAMAN ${ }^{\mathrm{b}}$, Nazlı BATAR ${ }^{\mathrm{c}}$, Sevil ŞAN ${ }^{\mathrm{d}}$
}

\section{ÖZET}

Amaç: Araştırma yoğun bakım ünitesinde sürekli ve bolus infüzyon ile beslenen hastaların kan glukozu regülasyonunun karşılaştırılması amacıyla yapılmıştır. Yöntem: Bu araştırma prospektif bir çalışma olup Ocak Nisan 2017 tarihleri arasında İstanbul Avrupa yakasında özel bir hastanenin dahili yoğun bakım ünitesinde tedavi görmekte olan 24 hasta üzerinde yapılmıştır. On sekiz yaş ve üzeri, sadece enteral yolla beslenen, en az üç gün yoğun bakım ünitesinde kalan hastalar çalışmaya dahil edilmiştir. Çalışmaya dahil edilen hastaların günde altı kere kan glukozu takipleri yapılmıştır. Bulgular: Araştırmaya katılanların \%54'ü kadın, \%46'sı erkek hastadır. Sürekli ve bolus infüzyonla beslenen hastalarda üç gün boyunca ölçülen kan glukoz değerlerinde istatistiksel olarak anlamlı bir değişiklik bulunmamıştır. Sonuçlar: Glukoz kontrolünü etkileyen faktörlerden biri beslenmedir. Nütrisyon ekibi beslenme konusunda duyarlı ve dikkatli olmalıdır. Hastalar nütrisyon ekibi tarafından değerlendirilmeli ve yoğun bakım süresince takip edilmelidir.

Anahtar kelimeler: Bolus infüzyon, enteral beslenme, kan glukoz regülasyonu, sürekli infüzyon

\section{Comparison of blood sugar regulations of patients fed with bolus and continuous infusion in the critical care unit}

\begin{abstract}
Objective: The research was carried out to compare blood glucose regulation of patients fed with continuous and bolus infusion in the critical care unit. Methods: This study is a prospective study and was performed on 24 patients who were treated in the internal intensive care unit of a private hospital in the European side of Istanbul between January-April 2017. Patients aged 18 and over who were fed enterally only for at least three days in the critical care unit were included in the study. Blood glucose follow-up was performed six times a day for the patients included in the study. Results: $54 \%$ of the patients were female and $46 \%$ were male. There was statistically no significant change in blood sugar measurements for three days in the patients fed continuous and bolus infusion. Conclusions: One of the factors affecting glucose control is nutrition. Nutrition team should be sensitive and careful about nutrition. Patients should be evaluated and monitored by the nutrition team in the critical care unit.
\end{abstract}

Keywords: Bolus infusion, enteral nutrition, blood sugar regulation, continuous infusion

\footnotetext{
Geliş Tarihi:06.05.2020 Kabul Tarihi:02.06.2020

aEmsal Karaca Beslenme ve Diyet Danıșmanlık Merkezi, İstanbul, Türkiye, e-posta: dytemsalkaraca@ gmail.com ORCID: 0000-0002-9315-9015 bDemiroğlu Bilim Üniversitesi, Sağlık Bilimleri Fakültesi, Beslenme ve Diyetetik Bölümü, İstanbul, Türkiye, e-posta: dytelifkaraman@gmail.com ORCID: 0000-0002-1425-6352

‘ístanbul Kültür Üniversitesi, Sağlık Bilimleri Fakültesi, Beslenme ve Diyetetik Bölümü, İstanbul, Türkiye, e-posta: n.batar@iku.edu.tr ORCID: 0000-00019527-5709

dMedikalpark Fatih Hastanesi, Beslenme ve Diyet Bölümü, , İstanbul, Türkiye, e-posta: sevilnas@ gmail.com ORCID: 0000-0002-8029-5202 


\section{GíRIŞ}

Besinlerin yeterli ve dengeli bir şekilde vücuda alınması, hücresel metabolizmayı çalıştırmak, korumak ve sağlığın geliştirilmesi için temel ihtiyaçlardan biridir. ${ }^{1}$

Malnütrisyon; protein, vitamin ve eser elementlerde eksikliklerin olduğu beslenme yetersizliğidir. Hastalık durumunda birey beslenme yetersizliğine daha duyarlı hale geldiğinden, birçok sağlık sorunlarının ortaya çıkması kolaylaşmaktadır. Yoğun bakıma kabul edilen hastaların kabul edildiklerinde veya kabul edildikten sonra kritik hastalığına bağlı olarak malnütrisyon gelişebileceği bildirilmiştir. $^{2} \quad$ Yapılan çalışmalar hastaların, hastalıklarına bağlı olarak, \%33-79'unun yetersiz beslendiğini göstermiştir. Daha da önemlisi tüm hastaların 2/3'ünün hastanede kaldıkları süre boyunca kilo kaybetmeye devam ettikleri gösterilmiştir. ${ }^{3}$ Hastane malnütrisyonu hastanın, beslenme durumunun bozulmasına yol açar veya var olan beslenme durumu bozukluğunun daha da derinleşmesine neden olur. Hastanede yatan hastalarda oluşan malnütrisyon kas, solunum, immün sistem fonksiyonlarında bozulmaya, yaşam kalitesinin azalmasına ve yaraların iyileşmesinde gecikmelere neden olmaktadır. Yoğun bakım ünitesinde yatan hastalar protein-enerji malnütrisyonuna girmeye yatkın bir gruptur. ${ }^{4} \mathrm{Bu}$ durum enfeksiyonlar ve organ yetmezliği gibi komplikasyonların oluşumuna neden olarak yoğun bakımda kalış süresini uzatmaktadır. Morbidite ve mortalitede de artışa neden olabilmektedir. Yoğun bakım ünitesinde takip edilen hastalara yeterli beslenme desteği verilmesi, malnütrisyonu ve ilişkili komplikasyonları önlemeye yardımcı olur. ${ }^{5} \mathrm{Bu}$ yüzden yoğun bakım hastalarında beslenme desteği günümüzde tedavinin ayrılmaz bir parçası olmuştur. 6 Yapılan çalışmalarda yeterli düzeyde beslenen hastaların yara iyileşmesinin düzeldiği immün yetersizliğin geri kazanıldığı, yeterli düzeyde beslenemeyen hastalarda ise morbidite ve mortalite hızlarının arttığı görülmektedir. ${ }^{7}$

Yoğun bakım ünitesinde üç günden uzun süre kalması ile oral alımı yetersiz olacağı düşünülen hastalara beslenme desteği başlanmalıdır. Beslenme desteği alacak olan hastanın durumuna göre enteral veya parenteral yollar tercih edilmektedir. Besin ögelerinin 7 günden daha uzun süre yetersiz alımında, malnütrisyon ve komplikasyonları durumunda, emilim kapasiteleri bozulduğunda klinik nütrisyon desteğine gerek duyulmaktadır. Klinik nütrisyon desteğine hastanın hemodinamiği ve metabolik dengesi sağlandıktan sonra başlanılmalıdır. ${ }^{3}$ Hemodinamik olarak stabil olan ve çalışan bir gastrointestinal sistem (GİS) yoluna sahip yoğun bakım hastaları için, erken (yoğun bakım ünitesine yatış sonrası 24-48 saat içinde) enteral beslenme önerilmesi tedavide standart hale gelmiştir. $^{2}$ Kritik hastalarda erken enteral beslenmeye başlanmasının hastanede kalış süresini kısalttığı ve ölüm oranlarını azalttığı bilinmektedir. ${ }^{8}$

Yoğun bakım hastalarında glukoz metabolizmasında belirgin değişiklikler gerçekleşmekte ve hiperglisemi görülmektedir. Hiperglisemi yara iyileşmesinde gecikmeye, enfeksiyon sıklığında artışa, mortalitenin artmasına neden olmaktadır. Yoğun bakım hastalarında insülin direncinin bir sonucu olarak karbonhidrat uygulamasına rağmen glukozun endojen üretimi yüksek kalır. Bu nedenle yoğun bakım ünitelerinde insülin uygulaması ve beslenme protokollerinin düzenlenmesi oldukça önemlidir. ${ }^{9}$

$\mathrm{Bu}$ araştırma yoğun bakım ünitesinde sürekli ve bolus infüzyon ile beslenen hastaların kan glukozu regülasyonunun karşılaştırılması amacıyla yapılmıştır.

\section{YÖNTEM}

Bu çalışma prospektif bir çalışma olup, Ocak 2017 Nisan 2017 tarihleri arasında İstanbul Avrupa yakasında özel bir hastanenin dahili yoğun bakım ünitesinde tedavi görmekte olan 24 hasta üzerinde yapılmıştır. Çalışmada yoğun bakım ünitesinde kalan sadece enteral yolla beslenen hastalar takip edilmiştir. üç gün boyunca sürekli infüzyon yöntemi ile beslenen hastaların ve üç gün boyunca bolus infüzyon yöntemi ile beslenen hastaların günde altı kere kan glukozu takipleri yapılmıştır. Çalışmaya $>18$ yaş, gebe olmayan, en az üç gün yoğun bakım ünitesinde kalan, beyin ölümü gerçekleşmemiş, diyabetin akut komplikasyonları (diyabetik ketoasidoz, hipoglisemi) olmayan hastalar dahil edilmiştir. Çalışma süresince enteral ürün ve miktarı, kullandığ 1 ilaçlar ve dozları aynı olan hastalar çalışmaya dahil edilmiştir.

Hastanın vücut ağırlığı, boyu, yaşı ve hastanın tanısı, kullandığı enteral ürün ve ürünün miktarı hasta takip formundan elde edilmiştir. Yoğun bakım ünitesinde izlem günlerinde günde altı kez olmak üzere saat 09:00, 13:00, 17:00, 21:00, 01:00, 05:00'de glukometre ile parmak ucundan kapiller kandan ölçülmüş ve kayıt edilmiştir.

Her iki beslenme yönteminde de nazogastrik beslenme tüpünün yeri kontrol edilerek ve hastaya 30$45^{0}$ yar1 oturur pozisyon verildikten sonra enteral ürünle beslenmiştir. Beslenmeye ara verildiği zamanlarda gastrik rezidü kontrol yapılmıştır. Hastaların beslenmelerinde düzenli kalibre edilmiş, infüzyon pompası kullanılmıştır. Hastaya hekimin order ettiği enteral ürün ve miktarı takip boyunca değiştirilmemiştir. Hastaların aldığı günlük enerji 
kayıt edilmiştir. Tüm hastalar 72 saat boyunca takip edilmiş ve tolerasyon yaşayan hastalar çalışmadan çıkarılmıştır.

Çalışmada enteral ürünlerin veriliş şekilleri, sürekli infüzyon ve bolus infüzyondur. Sürekli infüzyonda hastalar 18 saat beslenmiş, altı saat dinlendirilmiştir ve ardından rezidü kontrolü yapılmıştır. Bolus infüzyon ile beslenen hastalar günde dört kez saatlik infüzyon şeklinde beslenmiştir. Sürekli infüzyon ve bolus infüzyonla beslenen hastalar basit randomizasyona göre belirlenmiştir.

Çalışmanın etik kurul onayı bir vakıf üniversitesinin klinik etik kurulundan Ocak 2017 tarihinde alınmıştır. Her hasta yakınından gönüllü onay alınarak çalışma gerçekleştirilmiştir.

Verilerin değerlendirilmesinde tanımlayıcı istatistiklerden nitel ölçümler için sayı ve yüzde; sayısal ölçümler için ise ortalama, standart sapma, minimum ve maksimum değerler verilmiştir. Veriler normal dağılmadığı için parametrik olmayan testler kullanılmıştır. Bağımsız iki grubun sürekli bir bağımlı değişkenle karşılaştırılması için Mann-Whitney U testi, bağımsız üç grubun sürekli bağımlı bir değişkenle karşılaştırılması için Kruskall Wallis testi kullanılmıştır. Tüm testler 0.05 hata payı göz önüne alınarak değerlendirildi. İstatistiksel analizlerin tümü SPSS 23.0 Windows paket programı kullanılarak yapılmıştır.

\section{BULGULAR}

$\mathrm{Bu}$ çalışmaya 24 hasta dahil edilmiştir. Çalışmaya dahil edilen hastaların \%54'ü kadın, \%46's1 erkektir.
Hastaların ortalama yaşı $71.7 \pm 12$ yıl, ortalama vücut ağırlığg $71.92 \pm 14 \mathrm{~kg}$, ortalama boy uzunluğu $1.62 \pm$ 7 metredir. Hastaların beslenme şekillerinin \%50'si sürekli beslenme, \%50'si bolus beslenme ile gerçekleştirilmiştir.

Tablo 1 ve Tablo 2'de sürekli ve bolus infüzyonla beslenen hastaların kan glukoz düzeyindeki değişim gösterilmiştir.

Tablo 1. Sürekli beslenen hastaların üç günlük kan glukozu düzeyindeki değişim

\begin{tabular}{lcr}
\hline & \multicolumn{1}{c}{ Ort \pm SS } & \multicolumn{1}{c}{ Min- Max } \\
\hline 1.Gün & $149.45 \pm 31.27$ & $117.5-206.0$ \\
\hline 2.Gün & $151.94 \pm 31.65$ & $116.0-221.16$ \\
\hline 3.Gün & $155.26 \pm 38.12$ & $109.50-237.50$
\end{tabular}

Ki-kare $=0.086 ; p=0.958$

Tablo 2: Bolus beslenen hastaların üç günlük kan glukozu düzeyindeki değişim

\begin{tabular}{lll}
\hline & Ort \pm SS & Min- Max \\
\hline 1.Gün & $131.20 \pm 6.94$ & $122.50-146$ \\
\hline 2.Gün & $140.20 \pm 15.64$ & $125-167,17$ \\
\hline 3.Gün & $136.65 \pm 11.09$ & $121.50-155.53$
\end{tabular}

Ki-kare $=2.042 ; p=0.360$

Sürekli ve bolus infüzyonla beslenen hastaların 3 gün boyunca kan glukoz düzeyinde istatistiksel farklılık yoktur $(\mathrm{p}>0.05)$.

Tablo 3'de sürekli ve bolus beslenen hastaların üç günlük kan glukoz ortalaması gösterilmiştir.

Tablo 3: Sürekli ve bolus beslenen hastalar ile 1. 2. ve 3. gün arasındaki değişim

\begin{tabular}{|c|c|c|c|c|c|c|}
\hline & & Say1 & Ort \pm SS & Min- Max & $\begin{array}{c}\text { Mann- } \\
\text { Whitney U }\end{array}$ & $\mathrm{p}$ \\
\hline \multirow{2}{*}{$\begin{array}{l}\text { 1.gün kan } \\
\text { glukozu } \\
\text { ortalaması }\end{array}$} & $\begin{array}{l}\text { Sürekli } \\
\text { Beslenen }\end{array}$ & 12 & $149.46 \pm 31.27$ & $117.50-206$ & 56.0 & 0.378 \\
\hline & $\begin{array}{l}\text { Bolus } \\
\text { Beslenen }\end{array}$ & 12 & $131.21 \pm 6.94$ & $122.50-146$ & & \\
\hline \multirow{2}{*}{$\begin{array}{l}\text { 2.gün kan } \\
\text { glukozu } \\
\text { ortalaması }\end{array}$} & $\begin{array}{l}\text { Sürekli } \\
\text { Beslenen }\end{array}$ & 12 & $151.94 \pm 31.66$ & $116-221.16$ & 59.0 & 0.478 \\
\hline & $\begin{array}{l}\text { Bolus } \\
\text { Beslenen }\end{array}$ & 12 & $140.21 \pm 15.65$ & $125,50-167.17$ & & \\
\hline \multirow{2}{*}{$\begin{array}{l}\text { 3.gün kan } \\
\text { glukozu } \\
\text { ortalamas1 }\end{array}$} & $\begin{array}{l}\text { Sürekli } \\
\text { Beslenen }\end{array}$ & 12 & $155.26 \pm 38.12$ & $109,50-237.50$ & 55.0 & 0.347 \\
\hline & $\begin{array}{l}\text { Bolus } \\
\text { Beslenen }\end{array}$ & 12 & $136.65 \pm 11.09$ & $121,67-155.33$ & & \\
\hline
\end{tabular}

Sürekli ve bolus infüzyon ile beslenen hastalarda 1.,2. ve 3. gün ölçülen kan glukozundaki değişim istatistiksel olarak anlamlı değildir ( $\mathrm{p}>0.05)$. 


\section{TARTIŞMA}

Yoğun bakım tedavisinin bir parçası olan beslenme desteği yoğun bakım hastalarında beslenme yetersizliklerinin önlenmesinde ve hastaların tedavisinde hayati bir role sahiptir. Gastrointestinal sistemin fonksiyonel bütünlüğü sağlam ise beslenme desteği için ilk seçilen yol enteral beslenmedir. Bu yaklaşımın gastrointestinal bütünlüğü sağladığı ve bakteriyel translokasyonu azalttığ bilinmektedir. $^{10}$

Yoğun bakım ünitelerinde son zamanlarda kan glikoz kontrolünün sıkı bir şekilde yapılmasının üzerinde durulması sonucu yoğun bakım hastalarında hipogliseminin de daha sık görüldüğü gözlenmiştir. Özellikle ciddi hipogliseminin meydana gelmesinin mortalite için önemli olması nedeniyle yoğun bakım hastalarında hipoglisemi oluşumunu engellemek ve erken tedavinin başlanması oldukça önem taşımaktadır. ${ }^{11}$ Yoğun bakım hastalarında steroid kullanımı, vazopressör ajanların kullanımı, enteral ve parenteral beslenme, fazla miktarda glikoz içeren sıvı infüzyonları hiperglisemiye yol açmaktadır. ${ }^{12}$

Hiperglisemi ve hipoglisemi yoğun bakım hastalarında artmış ölüm riski oluşturmaktadır. ${ }^{13}$ Enteral beslenen hastaların glikoz cevabı, günlük enerji alımı, kullanılan beslenme solüsyonu, beslenme solüsyonunun verilme hızı ve yöntemine göre değişiklik göstermektedir. $\mathrm{Bu}$ çalışmada sadece enteral beslenen yoğun bakım ünitesinde kalan hastaların, glikoz cevabını etkileyen faktörler sabit tutulup sadece enteral besin solüsyonunun veriliş yöntemi değiştirilerek glikoz kontrolü üzerine etkisine bakılmıştır. Sürekli ve bolus infüzyon ile beslenen hastaların kan glukoz değerlerinde istatistiksel olarak anlamlı bir fark bulunmamıştır.

Enteral beslenme uygulanırken aspirasyon riskini en aza indirmek için sürekli beslenme yöntemi önerilmektedir. Yapılan çalışmalarda ise bolus beslenme yönteminin normal fizyolojiye ve beslenme ritmine daha uyumlu olabileceği, kan şekerlerinin daha iyi kontrol altına alınabileceği düşünülmektedir. ${ }^{14} \mathrm{Bu}$ çalışmamızda da üç gün boyunca kan glukoz düzeyinde anlamlı bir değişiklik saptanmamıştır. Literatürle benzerlik göstermektedir. Yapılan başka bir çalışmada ise enteral yolla beslenme yönteminin kan glukozu üzerine etkisine bakılmıştır. 1. gün sürekli enteral beslenme yöntemi, 2.gün aynı miktar ve enerji içeren beslenme solüsyonu ile gece 24'e kadar sürekli beslenme yöntemi uygulanarak iki yöntem arasındaki bekleme süresi sağlanmıştır. 3. gün aralıklı enteral beslenme yöntemi uygulanarak, 1 ve 3 . günde ki kan şekeri değerleri karşılaştırılmıştır. Sürekli ve aralıklı besleme yöntemlerinde glikoz değerleri karşılaştırılmış, aralıklı beslenme uygulanan gündeki glikoz değerleri, sürekli beslenme uygulanan güne göre daha düşük olduğu belirlenmiştir. Aralarındaki fark istatistiksel olarak anlamlı bulunmuştur. Aralıklı beslenmede günlük ortalama kan glukozu, sürekli beslenmeye göre düşük bulunmuştur. ${ }^{14} \mathrm{Bu}$ çalışmada bolus infüzyon ile beslenen hastaların üç gün boyunca kan glukoz düzeyinde anlamlı bir değişiklik saptanmamıştır.

Campbell ve arkadaşlarının yaptıkları bir çalışmada sürekli beslenme ve gece boyunca 10-16 saat periodla beslenme metodları karşılaştırılmıştır. Sürekli beslenenlerde daha fazla oksijen tüketimi ve katekolamin salınımı olduğu, sekiz saatlik sürenin her iki saatinde bir bolus beslenenlerde ise 24 saat sürekli beslenenlere göre daha iyi nitrojen dengesi olduğu gösterilmiştir. ${ }^{15} \mathrm{Bu}$ çalışmada sürekli ve bolus infüzyon ile beslenen hastalarda 1. 2. ve 3. gün ölçülen kan glukoz düzeyinde istatistiksel olarak anlamlı bir değişiklik olmamış ve birbirine benzer seyretmiştir. Sürekli infuzyonun ile bolus infuzyon ile beslenme durumunun kan glukozu üzerinde anlamlı farklılık yaratmadığı saptanmıştır. Çalışma süresinin kısa olması ve çalışmaya dahil edilen hasta sayısının az olması bu çalışmanın sınırlılığıdır.

\section{SONUC}

Yoğun bakım hastalarında glukoz kontrolü oldukça önem taşımaktadır. Glukoz kontrolünü etkileyen faktörlerden biri beslenmedir. Bu tarz çalışmalar daha fazla hasta sayıs1 ve 3 günden daha uzun takip edilerek daha geniş kapsamlı olarak yapılmalıdır. Nütrisyon ekibi beslenme konusunda daha duyarlı ve dikkatli olmalıdır. Hastalar yoğun bakım süresince nütrisyon ekibi tarafindan takip edilmelidir.

\section{KAYNAKLAR}

1. Evans DC, Forbes R, Jones $\mathrm{C}$ et al. Continuous versus bolus tube feeds: Does the modality affect glycemic variability, tube feeding volume, caloric intake, or insulin utilization. Int $\mathbf{J}$ Crit Illn Inj Sci. 2016;6(1):9-15.

2. Bayır H, Yıldız İ, Erkuran MK, Koçoğlu H. Yoğun bakım hastalarında malnütrisyon. Abant Medical Journal 2015;4:420-427.

3. Çetiner M, Kabay S, Ocak Ö, Ayas S. A case of iatrogenic wernicke encephalopathy following prolonged total parenteral nutrition. Mustafa Kemal Üniversitesi Tip dergisi.2018;34(9):99-104. doi:10.17944/mkutfd.410206

4. Aydıntuğ S, Sonyürek P, Soysal D. Klinik Nutrisyon.2.Basım İstanbul: Nobel Kitapevi; 2006.

5. Cahill NE, Dhaliwal R, Day, AG, Xuran J, Heyland DK. Critical Care Nutrition Clinical Pratice Guidelines. 2010;38(2):395-401. doi: 10.1097/CCM.0b013e3181c0263d 
6. Loss SH, Franzosi OS, Nunes DSL, Teixeira C, Viana LV. Seven deadly sins of nutrition therapy in critically Ill patients, Nutrition in Clinical Practice. 2019;35(2):205-210.

7. Montejo, J.C. Miñambres, E., Bordejé, L. et al. Gastric residual volume during enteral nutrition in ICU patients: the REGANE study. Intensive Care Med:2010;36:13861393.doi.org/10.1007/s00134-010-1856-y

8. Heyland, Daren K. MD, MSc; Cahill, Naomi RD, PhD (candidate); Day, Andrew G. MSc. Critical Care Medicine:2011;39(12):26192626. doi:10.1097/CCM.0b013e318226641d

9. Güvener M, Paşaoğlu I, Demircin M, Oc M. Perioperative hyperglycemia is a strong correlate of postoperative infection in type IIdiabetic patients after coronary artery bypass grafting. Endocr J. 2002;49:531-537.

10. Tekin E, Akan M, Koca U, ve ark. Enteral beslenme uygulanan yoğun bakım hastalarında farklı gastrik rezidüel volümlerin karşılaştırılması. J Turk Soc Intens Care. 2019;17:25-30.
11. Çelik S, Olgun N. Yoğun bakımda hpoglisemi ve hiperglisemi. Yoğun Bakım Hemşireliği Dergisi. 2016;20(1):57-64.

12. Dellinger RP, Levy MM, Rhodes A,et al. Uluslararasi ağır sepsis ve septik sokun yönetimi k1lavuzu: 2012. J Turk Soc Intens Care 2014;12:118-164.

13. Aygencel G, Türkoğlu M, Savaş G, Toruner F, Arslan M. Yoğun bakımda glisemik kontrol. Yoğun Bakım Dergisi. 2011;1:1-7

14. Acar Aktaş R. Enteral yoldan beslenen yoğun bakım hastalarının beslenme yönteminin glikoz kontrolüne etkisi. Türkiye Cumhuriyeti Acıbadem Üniversitesi Sağlık Bilimleri Enstitüsü, Yüksek Lisans Tezi, 2013, İstanbul (Danışman: Prof. Dr. Nermin Olgun)

15. Campbell IT, Morton RP, Cole JA, et al: A comparison of the effects of intermittent and contnuous nasogastric feeding on the oxygen consumption and nitrogen balance of patients after major head and neck surgery. Am J Clin Nutr. 1983;38(6):870-878. 